\title{
Performance of a 270 MW Gas Power Plant Using Exergy and Heat Rate
}

\author{
D. A. Aderibigbe*, G. Osunbor \\ Mechanical Engineering Department, Faculty of Engineering, University of Lagos, Akoka, Yaba, Lagos, Nigeria \\ Email: ^daader@gmail.com
}

How to cite this paper: Aderibigbe, D.A. and Osunbor, G. (2019) Performance of a 270 MW Gas Power Plant Using Exergy and Heat Rate. Energy and Power Engineering, 11, 15-34.

https://doi.org/10.4236/epe.2019.112002

Received: January 9, 2019

Accepted: February 18, 2019

Published: February 21, 2019

Copyright $\odot 2019$ by author(s) and Scientific Research Publishing Inc. This work is licensed under the Creative Commons Attribution International License (CC BY 4.0).

http://creativecommons.org/licenses/by/4.0/

\begin{abstract}
The performance of a $270 \mathrm{MW}(9 \times 30 \mathrm{MW})$ AES Corporation barge mounted gas turbine power plant in Nigeria is evaluated using the heat rate and entropy generation by the components of the plant to characterize the irreversibility in each component when operating at different loads between $90 \%$ and $25 \%$. The power plants have the peculiarity that three of the plants were supplied by three (3) different Original Equipment Manufacturers (OEM); A, B and C. This study is sequel to the fact that the gas turbines were the first independent power plants in the country and after more than fifteen years of operation, it is reasonable to evaluate the performance of the major components. By analyzing the thermodynamic performance of these components, the study demonstrates the utility value of exergy efficiency as an important parameter in the evaluation of major components in a gas power plant. Exergy efficiency is shown to be an important parameter in ranking the power plant components, identifying and quantifying the possible areas of reduction in thermodynamic losses and improvement in efficiencies. A new relationship is derived to demonstrate the correlation between the exergy efficiency and the heat rate of a $30 \mathrm{MW}$ gas power plant. The prediction of the derived relationship correlates well with the observed operational performance of the $30 \mathrm{MW}$ power plants. The combustion chamber in each of the plants provides the maximum exergy destruction during operation. Its exergy efficiency is shown to exhibit good correlation with its energy efficiency and the plant rational exergy. The implication is that from an operational and component selection viewpoint in the specifications of a gas power plant, knowledge of the Heat Rate which is usually provided by the OEM is adequate to make a reasonable inference on the performance of some critical components of the plant.
\end{abstract}

\section{Keywords}

Exergy Analysis, Gas Turbine Power Plant, Heat Rate, Efficiency and Performance 


\section{Introduction}

The Applied Energy Services (AES) Corporation barge-mounted gas turbine power plants located at Egbin, about $40 \mathrm{~km}$ North East of Lagos in Nigeria are the first Independent Power Plant (IPP) in the country with a total installed generating capacity of $270 \mathrm{MW}(9$ nos. $\times 30 \mathrm{MW}$ ). Each gas turbine drives a generator with an output voltage of $11.3 \mathrm{kV}$ that is stepped up to a terminal voltage of $132 \mathrm{kV}$ before connection to the National Grid. The power plants were brought to the site in 2001. After more than 15 years of operation, it is reasonable to evaluate the performance of the major components of the power plants.

The concept of Exergy of a system has been defined by Kotas [1], Dincer et al. [2], Egware and Obanor [3] and, Cengel and Boles [4] as the maximum shaft work that can be obtained from a system at a given state in a specified reference environment. Kotas [1] further highlighted the use of exergy in defining the criteria of performance in thermal plants. Exergy analyses of gas turbine power plants at different locations have also been reported by Ebadi and Gorji-Bandpy [5], Rosen and Bulucea [6].

Ali and Mohammad [7] also carried out exergy and exergo-economic analyses of a gas turbine power generating system. The results of the load variation of the gas turbine show that a reduction in gas turbine load results in a decrease in the exergy efficiency of the cycle as well as that of all the components. The advantage of using exergy analysis to identify possible areas of reduction in thermodynamic losses and improvement in efficiencies of major components of electrical power technologies and systems including gas turbine power plants are therefore well documented in the literature. The primary objective of the present study is threefold:

1) To analyze the thermodynamic performance of the major components of three operational gas power plants, each with a rated capacity of $30 \mathrm{MW}$ but from different Original Equipment Manufacturers (A, B and C) using both energy and exergy analysis,

2) To identify and quantify the exergy efficiency of the various components of each plant, and

3) To establish the relationship between the heat rate and the energy and exergy efficiencies of the plant.

\section{Methodology}

\subsection{Data Acquisition}

The study made use of the operational data of each of the three power plants. These include the daily records of the performance of each barge (A, B or C), mass flow of fuel, temperature and pressure at various states during generation (see Tables 1-3). Relevant plant and working fluid parameters, such as, air and fuel, specific capacities, relative gas constants and other constants were obtained from appropriate thermodynamic table [8]. The rated conditions are classified into cold rated condition and hot rated condition. The cold rated condition is 
Table 1. Operational data for the exergy analysis of the $30 \mathrm{MW}$ gas power plant, A, at $90 \%$ MCR.

\begin{tabular}{cccccccc}
\hline State & Definition of states & $\mathrm{m}(\mathrm{kg} / \mathrm{s})$ & $\mathrm{T}\left({ }^{\circ} \mathrm{k}\right)$ & $\mathrm{P}(\mathrm{bar})$ & $\mathrm{E}_{\mathrm{F}}(\mathrm{MW})$ & $\mathrm{E}_{\mathrm{T}}(\mathrm{MW})$ & $\mathrm{E}_{\mathrm{M}}(\mathrm{MW})$ \\
\hline 1 & AC inlet & 79.06 & 306.3 & 1.013 & 0 & 0.175 & 0.0087 \\
2 & AC exit/CC inlet & 79.06 & 642.96 & 9.00 & 0 & 3.9646 & 23.8689 \\
$\mathrm{~F}$ & Fuel & 2.23 & 299 & 22.00 & 163.04 & -0.0606 & 0.5874 \\
3 & CC exit/GT inlet & 81.29 & 1448.05 & 9.00 & 0 & 89.8655 & 70.6421 \\
4 & GT exit & 81.29 & 839.08 & 1.013 & 0 & 50.5033 & 20.9727 \\
\hline
\end{tabular}

Table 2. Operational data for the exergy analysis of the $30 \mathrm{MW}$ as power plant, B, at $90 \%$ MCR.

\begin{tabular}{cccccccc}
\hline State & Definition of states & $\mathrm{m}(\mathrm{kg} / \mathrm{s})$ & $\mathrm{T}\left({ }^{\circ} \mathrm{k}\right)$ & $\mathrm{P}(\mathrm{bar})$ & $\mathrm{E}_{\mathrm{F}}(\mathrm{MW})$ & $\mathrm{E}_{\mathrm{T}}(\mathrm{MW})$ & $\mathrm{E}_{\mathrm{M}}(\mathrm{MW})$ \\
\hline 1 & AC inlet & 74.01 & 300.19 & 1.013 & 0 & 0.001 & 0.0005 \\
2 & AC exit/CC inlet & 74.01 & 633.15 & 10.00 & 0 & 2.473 & 22.7164 \\
$\mathrm{~F}$ & Fuel & 2.43 & 299 & 22 & 173.04 & -0.0507 & 0.6400 \\
3 & CC exit/GT inlet & 76.44 & 1481.74 & 10.00 & 0 & 86.335 & 69.1779 \\
4 & GT exit & 76.44 & 839.08 & 1.013 & 0 & 147.490 & 19.7214 \\
\hline
\end{tabular}

Table 3. Operational data for the exergy analysis of the $30 \mathrm{MW}$ as power plant, C, at $90 \%$ MCR.

\begin{tabular}{cccccccc}
\hline State & Definition of states & $\mathrm{m}(\mathrm{kg} / \mathrm{s})$ & $\mathrm{T}\left({ }^{\circ} \mathrm{k}\right)$ & $\mathrm{P}(\mathrm{bar})$ & $\mathrm{E}_{\mathrm{F}}(\mathrm{MW})$ & $\mathrm{E}_{\mathrm{T}}(\mathrm{MW})$ & $\mathrm{E}_{\mathrm{M}}(\mathrm{MW})$ \\
\hline 1 & AC inlet & 80.20 & 303.15 & 1.013 & 0 & 0.0067 & 0.0033 \\
2 & AC exit/CC inlet & 80.20 & 632.22 & 10 & 0 & 2.6327 & 24.5767 \\
$\mathrm{~F}$ & Fuel & 2.47 & 299 & 22 & 175.04 & -0.0619 & 0.6506 \\
3 & CC exit/GT inlet & 82.67 & 1489.61 & 10 & 0 & 94.5168 & 75.3387 \\
4 & GT exit & 82.67 & 840.774 & 1.013 & 0 & 51.6167 & 21.4270 \\
\hline
\end{tabular}

when the ambient temperature is $25^{\circ} \mathrm{C}$ (see Table 1) and it is said to be hot rated if the ambient temperature is $37^{\circ} \mathrm{C}$ (see Table 2).

\subsection{Process Description and Isentropic Efficiencies of Major Components}

Figure 1 illustrates the schematic flow diagram of a typical $30 \mathrm{MW}$ gas power plant while Figure 2 shows the corresponding T-S diagram, that is, based on the Brayton thermodynamic cycle. The major components of the plants are: 1) the air compressor, 2) the combustion chamber and 3) the gas turbine units.

At state point 1, the compression phase is initiated as air is drawn into the compressor at ambient temperature, $T_{1}$ and atmospheric pressure, $P_{1}$ or PA. It is compressed by a multi-stage axial flow type compressor to an increased pressure, $P_{2}$ and temperature, $T_{2}$. The compressed air flows into the combustor at state point 2 , where it is mixed with the fuel and burned at a constant pressure. 


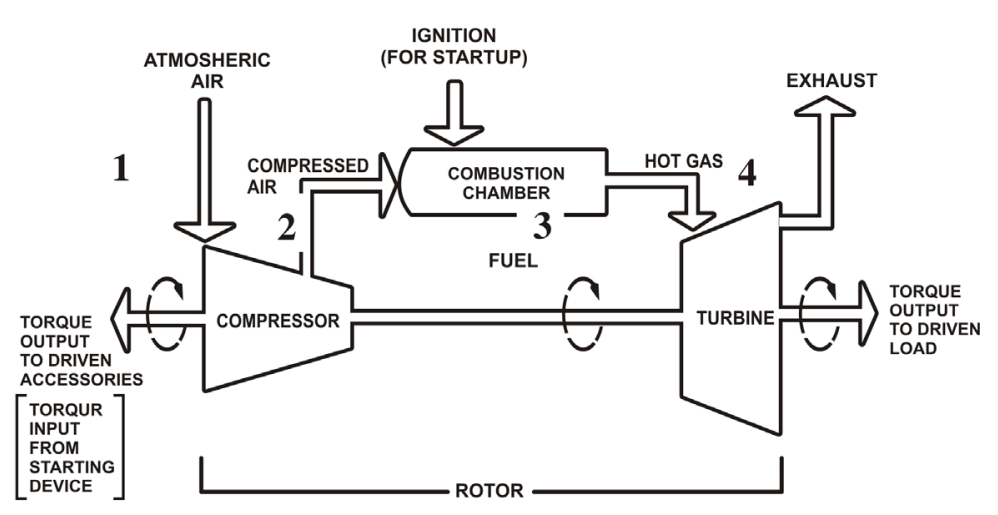

Figure 1. Flow diagram of AES $30 \mathrm{MW}$ gas turbine power plant.

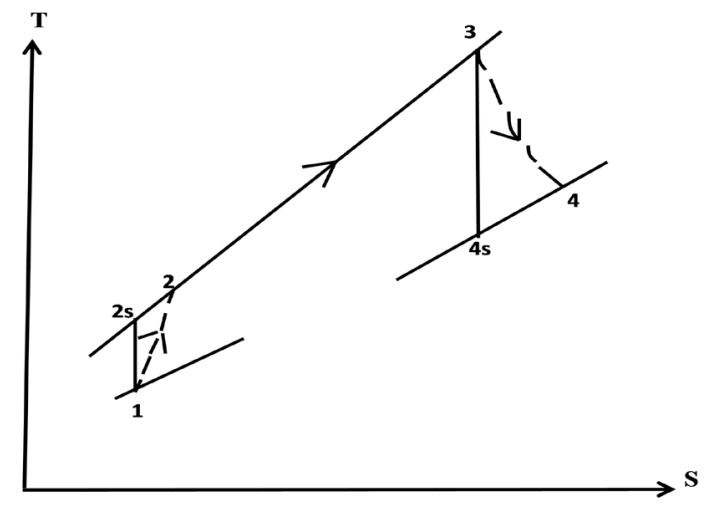

Figure 2. T-S Diagram for the AES gas turbine power plant.

At state point 3 the resulting hot gas, having the highest temperature, $T_{3}$ enters the turbine nozzle and is expanded through turbine section, producing mechanical power by rotating the shaft, which is connected to the generator for electric power generation. At state point 4, the exhaust gases are expanded back to atmospheric pressure, $P_{4}$ (or PA) and exhaust temperature, $T_{4}$.

In the ideal Brayton cycle, processes $1-2 \mathrm{~s}$ and $3-4 \mathrm{~s}$ are isentropi, with $P_{2}=$ $P_{3}$ and $P_{4}=P_{1}$.

Hence,

$$
T_{2 s} / T_{1}=\left(P_{2} / P_{1}\right)^{(k-1) / k}=\left(P_{3} / P_{4}\right)^{(k-1) / k}=T_{3} / T_{4 s}
$$

where $k=$ ratio of specific heat capacities.

The isentropic efficiencies of air compressor $\left(-\eta_{A C}\right)$ and of gas turbine $\left(\eta_{G T}\right)$ are obtained from

$$
\eta_{A C}=\left(T_{2 s}-T_{1}\right) /\left(T_{2}-T_{1}\right) \text { and } \eta_{G T}=\left(T_{3}-T_{4}\right) /\left(T_{3}-T_{4 s}\right)
$$

\section{General Exergy Balance for the Control Volume of the Gas Power Plant}

The statement of the General Exergy balance for the control volume in Figure 3 (an open system) states that the exergy change of a system during a process is equal to the difference between the net exergy transfer through the system 


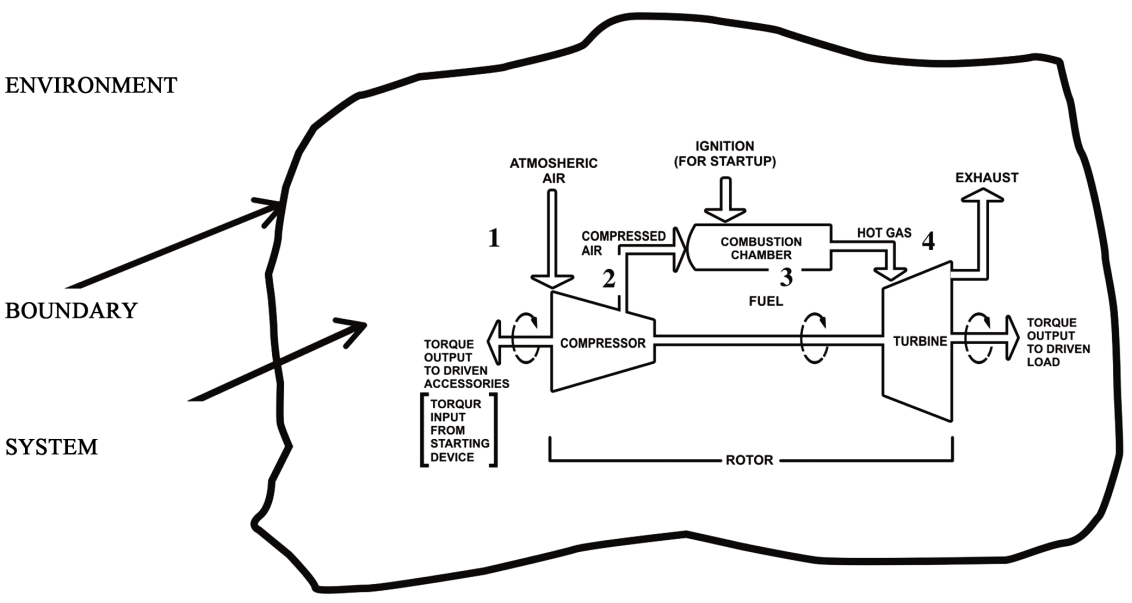

Figure 3. Control volume for the exergy analysis of AES gas power plant.

boundary by heat, work, mass flow and the exergy destroyed within the system the exergy destroyed within the system boundary as a result of ireversibility. Thus, we can write:

Net Exergy transfer(by heat, work and mass)

- Exergy destroyed consumption

$=$ Change in Exergy of the system

Thus exergy, a measure of energy quality or work potential, is consumed as a result of irreversibilities.

On the basis of Equation (3) we can write:

$$
\left(E_{\text {in }}-E_{\text {out }}\right)-E_{\text {destroyed }}=\Delta E_{\text {system }}
$$

where,

$\left(E_{\text {in }}-E_{\text {out }}\right)=$ Net exergy transfer (by heat, work and mass).

$E_{\text {destroyed }}=$ Exergy destruction in the system.

$\Delta E_{\text {system }}=$ Change in exergy of the system.

The above Equation (4) can also be expressed as:

$$
E_{\text {heat }}-E_{\text {work }}+E_{\text {mass,in }}-E_{\text {mass,out }}-E_{\text {destroyed }}=E_{2}-E_{1}
$$

where

Exergy transfer by heat, $E_{\text {heat }}=\Sigma\left(1-T_{0} / T_{C}\right) Q_{C}$.

Exergy transfer by work, $E_{\text {work }}=W-P_{0}\left(V_{j}-V_{i}\right)$.

Exergy transfer by mass into the system, $E_{\text {mass,in }}=\Sigma m_{\text {in }} \psi$.

Exergy transfer by mass out of the system, $E_{\text {mass,out }}=\Sigma m_{\text {out }} \psi$.

Substituting the above relations in Equation (5), the exergy balance for a control volume (Figure 3 ) is,

$$
\begin{aligned}
& \Sigma\left(1-T_{0} / T_{C}\right) Q_{C}-\left[W-P_{0}\left(V_{j}-V_{i}\right)\right]+\Sigma m_{\text {in }} \psi-\Sigma m_{\text {out }} \psi-E_{\text {destroyed }} \\
& =\left(E_{2}-E_{1}\right) c v
\end{aligned}
$$

where $\psi$ is the exergy content for a flow stream and it is given as $\psi=\left(h-h_{0}\right)-T_{0}\left(s-s_{0}\right)+v^{2} / 2+g_{a c c} * z$ and $P_{0}, h_{0}, T_{0}, s_{0}$, are the properties of 
the system evaluated at the dead state (i.e. the conditions of the environment).

$Q_{C}$ is the heat transfer through the boundary at temperature $T_{C}$ and location c.

$m_{\text {in }}$ and $m_{\text {out }}$ are the mass flowrate of working fluid at the inlet and exit locations of the system (gas turbine power plant unit).

From Equation (6), $W$ is the boundary work and may be written as:

$$
W=Q-\Delta U=Q-m\left(u_{j}-u_{i}\right)
$$

while $W-P_{0}\left(V_{j}-V_{i}\right)$ is the useful work, subscripts $i$ and $j$ denote the initial and final states of the system respectively during the process.

$V_{i}$ and $V_{j}$ are the respective volumes at states $i$ and $j$.

In the rate form, we can write

$$
\Sigma\left(1-T_{0} / T_{C}\right) \dot{Q}_{C}-\left[\dot{W}-P_{0} \mathrm{~d} V / \mathrm{d} t\right]+\Sigma \dot{m}_{\text {in }} \psi-\Sigma \dot{m}_{\text {out }} \psi-E_{\text {destroyed }}=\mathrm{d} E / \mathrm{d} t
$$

For steady flow process and single stream in the case of turbine and compressor, $V / \mathrm{d} t=0$ and $\mathrm{d} E / \mathrm{d} t=0$.

Hence, the rate form of the general exergy balance in Equation (3) above reduces to:

$$
\Sigma\left(1-T_{0} / T_{C}\right) \dot{Q}_{C}-\left[\dot{W}-P_{0} \mathrm{~d} V / \mathrm{d} t\right]+\Sigma \dot{m}_{\text {in }} \psi-\Sigma \dot{m}_{\text {out }} \psi-E_{\text {destroyed }}=0
$$

Or

$$
\dot{W}=\Sigma\left(1-T_{0} / T_{C}\right) \dot{Q}_{C}+\Sigma \dot{m}\left(\psi_{\text {in }}-\psi_{\text {out }}\right)-E_{\text {destroyed }}
$$

Substituting the exergy content $\psi=\left(h-h_{0}\right)-T_{0}\left(s-s_{0}\right)+v^{2} / 2+g_{a c c} * z$ into Equation (8) we can write

$$
\dot{W}=\Sigma\left(1-T_{0} / T_{C}\right) \dot{Q}_{C}+\Sigma \dot{m}\left[\left(h-h_{0}\right)-T_{0}\left(s-s_{0}\right)+v^{2} / 2+g_{a c c} * z\right]-\dot{E}_{\text {destroyed }}
$$

When changes in kinetic and potential energies are negligible, the useful work per unit time is therefore given by:

$$
\dot{W}=\Sigma\left(1-T_{0} / T_{C}\right) \dot{Q}_{C}+\Sigma \dot{m}\left[\left(h-h_{0}\right)-T_{0}\left(s-s_{0}\right)\right]-E_{\text {destroyed }}
$$

where $\dot{W}=$ Useful work per unit time or Exergy flow rate.

\subsection{Exergy Destruction ( $\left.E_{\text {destroyed }}\right)$ and Exergy Destruction Efficiency $\left(\varepsilon_{D}\right)$}

The exergy destruction in the system (gas power plant) is defined as the loss of available energy of the system. The exergy destruction efficiency is the ratio of exergy destroyed to the rate of exergy flow of fuel in the plant. That is,

$$
\varepsilon_{D}=100 * \dot{E}_{\text {destroyed }} / \dot{E}_{F}
$$

From Equation (9) above, the useful work per unit time can be written as:

$$
\underline{\dot{W}}=\underline{\dot{W}}_{\text {rev }}-\dot{E}_{\text {destroyed }}
$$

where, $\underline{\dot{W}}_{\text {rev }}$ is the reversible work per unit time and is given by:

$$
\underline{\dot{W}}_{\text {rev }}=\Sigma\left(1-T_{0} / T_{C}\right) \dot{Q}_{C}+\dot{m}\left[\left(h-h_{0}\right)-T_{0}\left(s-s_{0}\right)\right] \text {, (since } \dot{E}_{\text {destroyed }}=0 \text { ) }
$$

For the Compressor and the Gas turbine, the Exergy destroyed can be deter- 
mined from the Guoy-Stodola relation of Equation (11) below

$$
\begin{aligned}
\dot{E}_{\text {destroyed }} & =T_{0} \dot{S}_{\text {gen }} \\
& =T_{0}\left[\dot{m}_{a}\left(s_{1}-s_{2}\right)+\dot{Q}_{\text {surr }} / T_{0}\right](\text { for the compressor }) \\
& =T_{0}\left[\dot{m}_{g}\left(s_{4}-s_{3}\right)+\dot{Q}_{\text {surr }} / T_{0}\right](\text { for the turbine })
\end{aligned}
$$

where $\dot{S}_{g e n}=$ Entropy generation.

$\dot{Q}_{\text {sur }}=$ Heat loss per unit time to the surrounding.

$T_{0}=$ Reference temperature or dead state temperature.

\subsection{Rational Exergy Efficiency, $\varepsilon_{\mathrm{p}}$}

\section{Formulation}

The rational exergy efficiency is defined [1] as the ratio of the desired exergy output (i.e. exergy recovered or actual useful exergy) to the exergy used (i.e. exergy supplied). It is given by;

$$
\begin{aligned}
\varepsilon_{p} & =(\text { exergy recovered }) /(\text { exergy supplied }) \\
& =(\text { exergy supplied }- \text { exergy destroyed }) / \text { exergy supplied } \\
& =1-(\text { exergy destroyed } / \text { exergy supplied }) p
\end{aligned}
$$

For an adiabatic turbine,

$$
\varepsilon_{\text {turb }}=\dot{\underline{W}}_{\text {out }} / \underline{\dot{W}}_{\text {rev, out }}=\left(h_{3}-h_{4}\right) /\left(\psi_{3}-\psi_{4}\right)=1-T_{0} \dot{S}_{\text {gen }} /\left(\psi_{3}-\psi_{4}\right)
$$

where, $\psi_{3}-\psi_{4}=\left(h_{3}-h_{4}\right)-T_{0}\left(s_{3}-s_{4}\right)$.

For an adiabatic compressor,

$$
\varepsilon_{\text {comp }}=\dot{\underline{W}}_{r e v, \text { oin }} / \dot{W}_{i n}=\left(\psi_{2}-\psi_{1}\right) /\left(h_{2}-h_{1}\right)=1-T_{0} \dot{S}_{\text {gen }} /\left(h_{2}-h_{1}\right)
$$

where

$$
\psi_{2}-\psi_{1}=\left(h_{2}-h_{1}\right)-T_{0}\left(s_{2}-s_{1}\right)
$$

In Equation (9), If we let

$$
\dot{E}_{M}=\dot{m}\left[\left(h-h_{0}\right)-T_{0}\left(s-s_{0}\right)\right] \text { and } \dot{E}_{T}=\left[1-T_{0} / T_{C}\right] \dot{Q}_{C}=\dot{Q}_{C}-T_{0} \dot{Q}_{C} / T_{C}
$$

Since, $h-h_{0}=c_{p}\left(T-T_{0}\right)$ and $s-s_{0}=c_{p} \ln \left(T / T_{0}\right)+R \ln \left(P_{0} / P\right)$

Then,

$$
\dot{E}_{M}=\dot{m} c_{p}\left[\left(T-T_{0}\right)-T_{0} \ln \left(T / T_{0}\right)-R\left(T_{0} / c_{p}\right) \ln \left(P_{0} / P\right)\right]
$$

where $\dot{E}_{M}=$ Mechanical exergy stream of component.

For a reversible process involving a perfect gas with a unit mass,

$$
\dot{Q}_{C}=T_{C}\left(s-s_{0}\right) \text { and } s-s_{0}=c_{p} \ln \left(T / T_{0}\right)+R \ln \left(P_{0} / P\right)
$$

Therefore, $\dot{Q}_{C}=T_{C}\left[c_{p} \ln \left(T / T_{0}\right)+R \ln \left(P_{0} / P\right)\right]$ and for a mass flowrate, $\dot{\mathrm{m}}$, we can write,

$$
\dot{E}_{T}=\dot{m}\left(T_{C}-T_{0}\right)\left[c_{p} \ln \left(T_{C} / T_{0}\right)+R \ln \left(P_{0} / P_{C}\right)\right]
$$

where $\dot{E}_{T}=$ Thermal exergy stream of the component. 


\subsection{Chemical Exergy of a Fuel Stream, $\dot{E}_{F}$}

Chemical exergy of a fuel stream is defined as the maximum work that can be obtained from the fuel by taking it to chemical equilibrium with the reference environment at constant temperature and pressure. The determination of the chemical exergy of fuel is a particular case of the calculation of the chemical exergy of a stream and is of great interest in the analysis of industrial facilities because it measures the amount of energy released from the energy carrier (fuel) as the components in the energy carrier are brought into reaction with reference substances (composition of air at $25^{\circ} \mathrm{C}$ and 1 atm pressure) present in the environment.

An approximate determination of the specific chemical exergy of industrial fuels can be easily carried out through empirical coefficients $f_{l}$ and $f_{h}$ [9] which relate it to the lower or higher heating values, i.e.

$$
\dot{E}_{F}=f_{l} * L H V=f_{h} * H H V
$$

where $\dot{E}_{F}$ denotes the chemical exergy of fuel.

In this study, we assume the relationship [4] [9] to be that of Equation (15), i.e.

$$
\dot{E}_{F}=\left(1.0308+\dot{m}_{F}\right) * L H V
$$

Taking note of the various components defined by Equation (9), the general exergy balance equation can be written as:

$$
\dot{E}_{F}+\dot{E}_{T}+\dot{E}_{M}-\dot{E}_{\text {destroyed }}=\dot{W}
$$

where $\dot{W}$ denotes the Exergy flow rate of the system, and

$\dot{E}_{F}=$ Chemical exergy of fuel.

$\dot{E}_{T}=$ Thermal exergy stream of the component under consideration.

$\dot{E}_{M}=$ Mechanical exergy stream of the component under consideration.

\subsection{Combustion Efficiency, $\boldsymbol{\eta}_{\mathrm{cc}}$}

The combustion chamber provides the heat for the working substance (air and fuel) in a gas turbine power plant. In practice the characteristics of a gas power plant are primarily determined by the reliability, starting properties, long service life, and the economy of operation of the combustion chamber [10]. The combustion efficiency is obtained from the relation:

Heat supplied by fuel $=$ Heat taken by burning gas

$$
\text { i.e. } \dot{m}_{F} * L H V * \eta_{c c}=\dot{m}_{g} * c_{P} *\left(T_{3}-T_{2}\right)
$$

where $\eta_{c c}$ is the combustion efficiency.

\subsection{Heat Rate (HR) of the Gas Power Plant}

The Net Plant Heat rate is defined as the amount of fuel energy input required to generate a kWh of electricity. Mathematically,

Heat rate $(\mathrm{kJ} / \mathrm{kWh})=$ Input Energy $(\mathrm{kJ} / \mathrm{h}) /$ Output Power $(\mathrm{kW})$ 
The heat rate is simply the inverse of the energy efficiency. Thus, If the plant efficiency is increased, the heat rate is lowered, and the better the plant is running because it is consuming less fuel. The plant heat rate is a measure of the combined performance of the gas turbine cycle and any other associated auxiliaries. When calculating the plant heat rate, the energy input to the system is the chemical energy in the fuel. Thus, Chemical energy of fuel = Total fuel used $(\mathrm{kg} / \mathrm{h}) \times$ LHV $(\mathrm{kJ} / \mathrm{kg})$, we can therefore write,

Net plant heat rate $(\mathrm{kJ} / \mathrm{kWh})$

$=($ Chemical energy of fuel, $\mathrm{kJ} / \mathrm{h}) /($ Net Output power, $\mathrm{kW})$

\subsection{Relationship between Exergy Efficiency $\left(\varepsilon_{p}\right)$ and Heat Rate (HR) of a Gas Power Plant}

Equation (12a) defines the exergy efficiency, $\mathcal{E}_{p}$, to be

$$
\begin{aligned}
\varepsilon_{p} & =1-(\text { exergy destroyed }) /(\text { exergy supplied }) \\
& =1-E_{\text {destroyed }} /(\text { Available energy in Fuel }) \\
& =1-E_{\text {destroyed }} / E_{F}
\end{aligned}
$$

Similarly, Equation (18) defines the heat rate, HR, to be

$$
\begin{aligned}
\mathrm{HR} & =\text { Chemical energy of fuel } / \text { Net output power } \\
& =\text { Chemical energy of fuel } / P_{\text {out }}
\end{aligned}
$$

where, $P_{\text {out }}$ is the net output power from the plant in $\mathrm{kW}$.

Equation (20) gives

$$
\text { Chemical Energy of fuel }=\mathrm{HR} * P_{\text {out }}=\text { Input Energy }
$$

The exergy destroyed in the plant, $E_{\text {destroyed }}$, is the sum of exergy destroyed in the air compressor $\left(E_{\mathrm{DAC}}\right)$, combustion chamber $\left(E_{\mathrm{Dcc}}\right)$ and the gas turbine $\left(E_{\mathrm{DGT}}\right)$. Thus,

$$
E_{\text {destroyed }}=E_{\mathrm{DAC}}+E_{\mathrm{Dcc}}+E_{\mathrm{DGT}}
$$

From the operational data in Tables 1-3, Equation (22) yields

$$
34.45 \mathrm{MW}=1.80 \mathrm{MW}+32.08 \mathrm{MW}+0.57 \mathrm{MW}
$$

Thus,

$$
E_{\text {destroyed }}=1.08 * E_{\text {Dcc }}
$$

i.e. the exergy destruction in the plant is 1.08 times the exergy destruction in the combustion chamber.

But the exergy destroyed in the combustion chamber,

$$
E_{\mathrm{Dcc}}=\text { Chemical energy of fuel } * \eta_{c c}
$$

where $\eta_{c c}$ is the thermal efficiency of the combustion chamber.

Also, the exergy supplied to the plant,

$$
E_{F}=\text { Exergy in the combustion chamber }=\dot{m}_{F} * 3600 * L H V
$$

where $\dot{m}_{F}$, is the mass flow rate of the fuel in $\mathrm{kg} / \mathrm{s}$.

Substituting Equations (21), (23), (24) and (25) into Equation (19) yields 


$$
\varepsilon_{p}=1-\left[1.08 *(H R) * P_{\text {out }} * \eta_{c c}\right] /\left[\dot{m}_{F} * 3600 *(L H V)\right]
$$

where $\varepsilon_{p}$ is the exergy efficiency of the plant.

Equation (26) is the derived relationship between the exergy efficiency and the heat rate of the gas power plant. It shows that the exergy efficiency of a power plant can be estimated for a given heat rate provided we know the output power, mass flow rate of the fuel and the thermal efficiency of the combustion chamber.

\subsection{Assumed Constants in the Analysis}

In this study, the following thermodynamic constants are used in the calculations:

Specific gas constant, $R=0.287 \mathrm{~kJ} / \mathrm{kg} \mathrm{K}$.

Specific heat capacity at constant pressure for air, $C_{p a}=1.005 \mathrm{~kJ} / \mathrm{kg} \mathrm{K}$. Specific heat capacity at constant pressure for exhaust gas, $c_{p g}=1.11 \mathrm{~kJ} / \mathrm{kg} \mathrm{K}$. Convective heat transfer coefficient, hcoeff $=50 \mathrm{~W} / \mathrm{m}^{2} \mathrm{~K}$.

LHV of fuel (methane) $=50,000 \mathrm{~kJ} / \mathrm{kg}$.

\subsection{Reference Conditions}

The reference conditions assumed for the power plant in the analysis are:

$T_{0}=298.150 \mathrm{~K}$ (for cold rated condition).

$T_{0}=310.150 \mathrm{~K}$ (for hot rated condition).

$P_{0}=1.013$ bars.

\section{Exergy Analysis of a $30 \mathrm{MW}$ AES Gas Power Plant}

The following assumptions are made in the analysis:

1) The kinetic and potential exergies are negligible.

2) The system (Gas turbine plant) is real, i.e. non-isentropic processes are considered for the analysis.

3) Heat losses through conduction and radiation are considered negligible.

4) The processes in the system are steady flow processes.

The exergy balance equation for each of the major components of the AES Gas Turbine plant can be derived from the general exergy balance equation given in Equation (16).

Using the states as represented in the T-S diagram for the plant (given in Figure 2), the exergy balance equation for each of the gas power plant components is as follow:

\subsection{Air Compressor}

$$
E_{T}+E_{M}-\dot{E}_{\text {destroyed }}=\dot{W}_{A C}
$$

\subsection{Combustion Chamber}

$$
\left(E_{F}+E_{T}+E_{M}\right)-\dot{E}_{\text {destroyed }}=\dot{Q}_{\text {surr }}
$$

where $\dot{Q}_{\text {surr }}$ denotes the heat transfer rate between the combustion chamber 
and the environment.

\subsection{Gas Turbine}

$$
E_{T}+E_{M}-\dot{E}_{\text {destroyed }}=\dot{W}_{G T}
$$

where

$\dot{W}_{A C}=$ Exergy flowrate of air compressor.

$\dot{W}_{G T}=$ Exergy flowrate of gas turbine.

$E_{F}=$ Chemical exergy of fuel.

$E_{T}=$ Thermal exergy stream of the component in consideration.

$E_{M}=$ Mechanical exergy stream of the component in consideration.

$\dot{E}_{\text {destroyed }}=$ Exergy destruction rate.

The above terms are evaluated from the relations of Equations (11), (13), (14) and (15).

\subsection{The Following Entropy Changes Should Also Be Noted}

$$
\begin{gathered}
s_{2}-s_{1}=c_{p} \ln \left(T_{2} / T_{1}\right)+R \ln \left(P_{1} / P_{2}\right) \text { for compression process } \\
s_{4}-s_{3}=c_{p} \ln \left(T_{4} / T_{3}\right)+R \ln \left(P_{3} / P_{4}\right) \text { for expansion process } \\
s_{3}-s_{2}=c_{p} \ln \left(T_{3} / T_{2}\right) \text { for combustion process }
\end{gathered}
$$

\section{Results and Discussion}

\subsection{Exergy Analyses of the 30 MW Gas Power Plants}

Table 4 shows the results of the exergy analysis for the gas power plant A at 90\% maximum continuous rating (MCR). Similar results were also obtained for the gas power plants $\mathrm{B}$ and $\mathrm{C}$. The exergy flow rate of the net power output for plant A is $57.78 \mathrm{MW}$ compared with $60.43 \mathrm{MW}$ for plant $\mathrm{B}$ and $67.07 \mathrm{MW}$ for plant C. In the case of the total exergy destruction, plant $\mathrm{A}$ is found to be $34.40 \mathrm{MW}$ while the corresponding exergy destructions in plants B and C are 46.04 MW and $35.58 \mathrm{MW}$ respectively. Thus, the loss of available energy of the system is maximum in plant $B$.

Table 4. Exergy flow rate, exergy destruction, exergy destruction efficiency and rational exergy efficiency for $30 \mathrm{MW}$ gas power plant A at 90\% MCR.

\begin{tabular}{ccccccccc}
\hline COMPONENT & $\begin{array}{c}\dot{W} \\
(\mathrm{MW})\end{array}$ & $\begin{array}{c}\dot{E}_{F} \\
(\mathrm{MW})\end{array}$ & $\begin{array}{c}\dot{E}_{T} \\
(\mathrm{MW})\end{array}$ & $\begin{array}{c}\dot{E}_{M} \\
(\mathrm{MW})\end{array}$ & $\begin{array}{c}\dot{E}_{D} \\
(\mathrm{MW})\end{array}$ & $\begin{array}{c}\dot{Q}_{\text {surr }} \\
(\mathrm{MW})\end{array}$ & $\varepsilon_{D}(\%)$ & $\mathcal{\varepsilon}(\%)$ \\
\hline Compressor & -30.71 & 0 & -3.95 & -23.96 & 2.81 & 0.017 & 1.72 & 90.86 \\
Combustion & 0 & -163.04 & 85.96 & 46.09 & 31.05 & 0.058 & 19.04 & 80.96 \\
chamber & & & & & & & & \\
Gas Turbine & 88.49 & 0 & 39.36 & 49.67 & 0.54 & 0.027 & 0.33 & 99.39 \\
Total plant & 57.78 & -163.04 & 121.38 & 71.8 & 34.4 & 0.102 & 21.1 & 35.44 \\
\hline
\end{tabular}


The exergy efficiency of the air compressor in plant A is $90.86 \%$ compared with the corresponding values of $92.42 \%$ and $93.26 \%$ in plants B and C respectively. The turbine section in plant A has an exergy efficiency of $99.39 \%$ compared with $99.30 \%$ and $99.40 \%$ in plants B and C respectively. Thus, from a practical standpoint, the three plants (A, B and $\mathrm{C}$ ) have turbines with identical performance.

The combustion chamber in plant A has the exergy destruction efficiency of $19.04 \%$ while the corresponding values for plants B and C are $25.06 \%$ and $18.87 \%$ respectively.

The rational exergy efficiency of the overall 30MW gas power plant is $35.44 \%$ in plant $\mathrm{A}$ and the corresponding values in plants $\mathrm{B}$ and $\mathrm{C}$ are $34.92 \%$ and $38.32 \%$ respectively. Thus, the actual useful energy is maximum in plant C.

\subsection{Energy Efficiencies of the Major Components of Gas Power Plants A, B and C}

Table 5 shows the results of the computed energy efficiencies of the major components of the three gas power plants. The air compressor of gas power plant $\mathrm{C}$ has the highest isentropic efficiency of $85.10 \%$ while the combustion chamber of the gas power plant A has the highest energy efficiency of $58.99 \%$. The isentropic efficiencies of the turbines in gas power plants $\mathrm{B}$ and $\mathrm{C}$ are identical at $90.70 \%$.

\subsection{Exergy and Energy Efficiencies of the Combustion Chambers in 30 MW Gas Power Plants}

When compared to other major components of the gas power plant, the exergy efficiency of the combustion chamber was found to significantly increase with the gas turbine inlet temperature as shown in Figure 4 for plant A.

This makes the combustion chamber the choice component to be optimized in the overall performance of the gas power plant. The correlation between the exergy and energy efficiencies of the combustion chamber in $30 \mathrm{MW}$ gas power plants in the study is shown in Figure 5 to follow the relation:

$$
\varepsilon_{c c}=9.56+1.22 * \eta_{c c}
$$

with a correlation coefficient of 0.966 .

Table 5. Energy efficiencies of the major components of the three gas power plants.

\begin{tabular}{cccc}
\hline \multirow{2}{*}{ Efficiencies of various units } & \multicolumn{2}{c}{ OEM of 30 MW GAS POWER PLANTS } \\
\cline { 2 - 4 } & $\mathrm{A}$ & $\mathrm{B}$ & $\mathrm{C}$ \\
\hline Isentropic efficiency of compressor (\%) & 78.84 & 83.30 & 85.10 \\
Isentropic efficiency of Turbine (\%) & 90.59 & 90.70 & 50.70 \\
Combustion Chamber energy efficiency (\%) & 58.99 & 53.65 & 57.68 \\
\hline
\end{tabular}




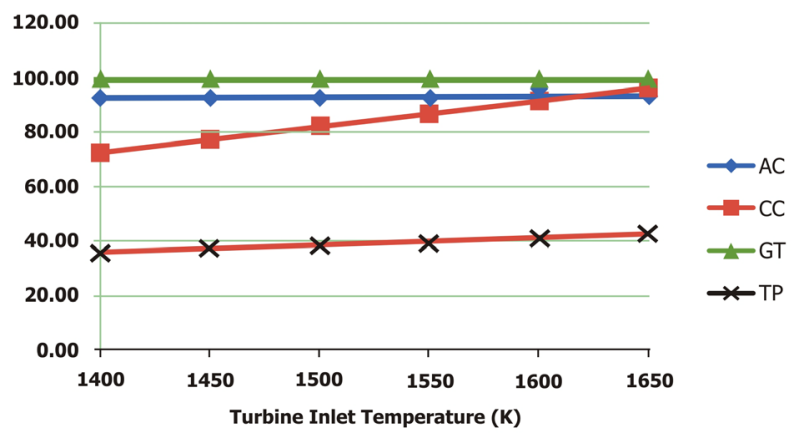

Figure 4. Change in overall plant rational exergetic efficiency with turbine inlet temperature for AES Gas Power Plant at 90\% MCR.

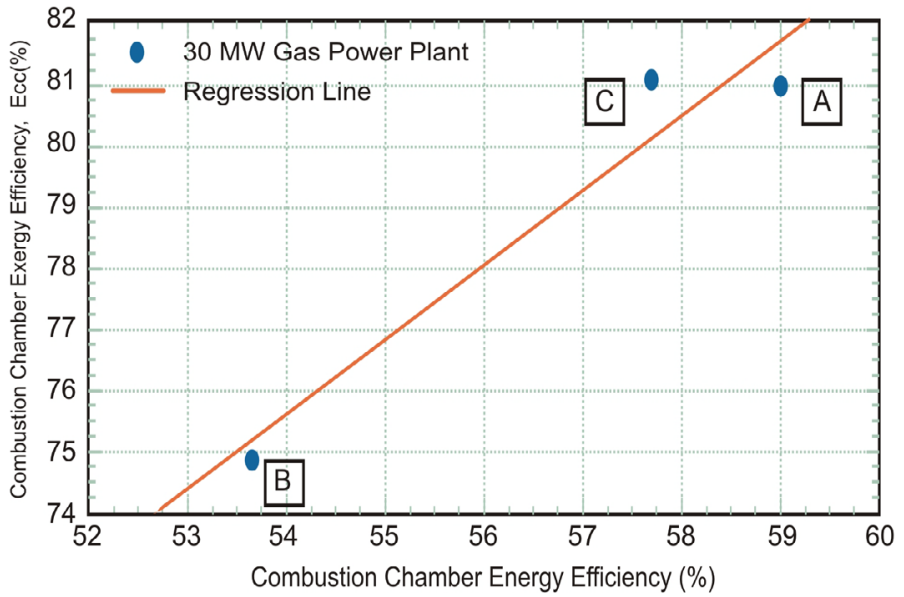

Figure 5. Correlation between the combustion chamber exergy and energy efficiencies in a $30 \mathrm{MW}$ gas power plant.

\subsection{Rational Exergy Efficiency $\left(\varepsilon_{p}\right)$ and Heat Rate (HR) of the 30 MW Gas Power Plants}

The results of the operational data of heat rate, actual output power, fuel mass flow rate and computed rational exergy efficiency of each gas power plant are compared with the predicted rational exergy efficiency according to Equation (26) in Table 6. The table shows that from consideration of the operational heat rate of the plants, plant $\mathrm{C}$ is the most fuel efficient followed by plant $\mathrm{A}$, while plant $B$ is the least efficient. In the case of the prediction, we have assumed the output power to be $30 \mathrm{MW}$ while the heat rate and the fuel mass flow rate have been assumed to be the average operational values for the three turbines of $14,100 \mathrm{~kJ} / \mathrm{kWh}$ and $2.38 \mathrm{~kg} / \mathrm{s}$ respectively. The combustion chamber energy efficiencies in Table 5 have been used in the prediction. The gas power plant $\mathrm{B}$ can be seen to exhibit the maximum deviation in exergy efficiency of about $21.5 \%$ from the calculated operational value of $34.9 \%$ while the plants A and C exhibited deviations of about $4.7 \%$ and $0.4 \%$ respectively from the computed operational values of $35.4 \%$ and $38.3 \%$ In general it can be deduced that Equation (26) is a reasonable relationship between the rational exergy efficiency and the heat rate of a gas power plant. 
Also, from Equation (26), the rational exergy efficiency can be seen to increase with increasing mass flow rate of the fuel at a given heat rate and combustion chamber thermal efficiency. The maximum theoretical mass flow rate of the fuel, $\left(\dot{m}_{F}\right)_{\max }$, will correspond to when the rational exergy efficiency approaches the Carnot efficiency, $\eta_{\text {carnot}}$, of the gas power plant. The Carnot efficiency of a 30 MW gas power plant can be computed from the relation,

$$
\eta_{\text {carnot }}=\left(T_{3 a v}-T_{0}\right) / T_{3 a v}
$$

where $T_{3 a v}=1473.13 \mathrm{~K}$ is the average value of the operational inlet temperature to the turbine for the three gas power plants. $T_{0}$ is the reference temperature. Thus, $\eta_{\text {carnot }}$ can be computed to be $0.7976 \%$ or $79.76 \%$. Using this value in Equation (26) for a $30 \mathrm{MW}$ gas power plant, with $\eta_{\mathrm{cc}}=0.59, H R=14,100 \mathrm{~kJ} / \mathrm{kwh}$, gives the theoretical maximum mass flow rate of fuel as $\left(\dot{m}_{F}\right)_{\max }=7.40 \mathrm{~kg} / \mathrm{s}$. The average operational value of $\dot{m}_{F}=2.38 \mathrm{~kg} / \mathrm{s}$ shows that about one-third of the theoretical maximum mass flow rate of fuel is used in practice. Figure 6 shows the non-linear regression relation between the rational exergy efficiency and the mass flow rate of fuel to be,

$$
\varepsilon_{p}=95.80-433.75 /\left(1+2.18 * \dot{m}_{F}\right)
$$

with a correlation coefficient of 1.00 .

Figure 7 also shows that in the $30 \mathrm{MW}$ gas power plants in the study, the exergy efficiency of the combustion chamber may be expressed as a function of the rational exergy efficiency of the plant with the following relation:

$$
\varepsilon_{c c}=-4523+250 * \varepsilon_{p}-3.4 * \varepsilon_{p}^{2}
$$

with a correlation coefficient of 1.0.

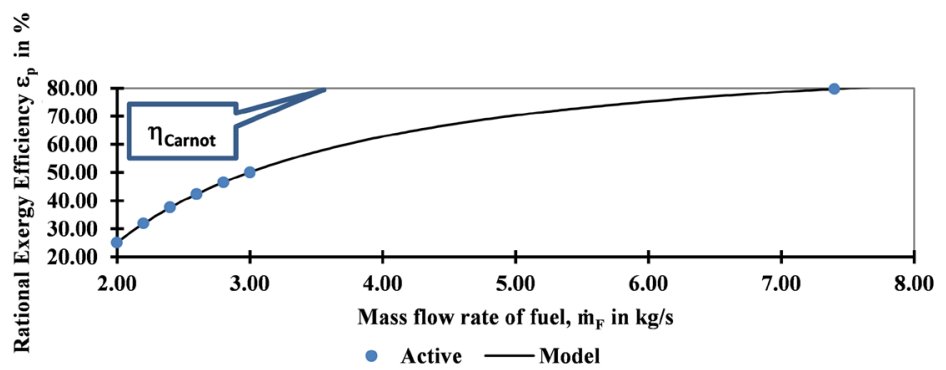

Figure 6. Nonlinear regression of Exergy efficiency $\left(\varepsilon_{\mathrm{p}}\right)$ of a $30 \mathrm{MW}$ Gas Power Plant as a function of Mass flow rate of fuel $\left(\dot{m}_{F}\right)$ for $\mathrm{HR}=14,100 \mathrm{~kJ} / \mathrm{kWh}$ and $\eta_{\mathrm{cc}}=0.59$.

Table 6. Comparison and validation of the predicted data with operational data for the exergy efficiency of $30 \mathrm{MW}$ gas power plant.

\begin{tabular}{ccccccc}
\hline $\begin{array}{c}\text { Gas } \\
\begin{array}{c}\text { Power } \\
\text { Plant }\end{array}\end{array}$ & $\begin{array}{c}\mathrm{P}_{\text {out }} \\
(\mathrm{MW})\end{array}$ & $\begin{array}{c}\text { Fuel mass } \\
\text { flow rate, } \\
(\mathrm{kg} / \mathrm{s})\end{array}$ & $\begin{array}{c}\text { Combustion } \\
\text { Chamber } \\
\text { Energy } \\
\text { Efficiency (\%) }\end{array}$ & $\begin{array}{c}\text { Operational } \\
\text { Plant Heat } \\
\text { Rate }(\mathrm{kJ} / \mathrm{kWh})\end{array}$ & $\begin{array}{c}\text { Operational } \\
\text { Plant Exergy } \\
\text { Efficiency (\%) }\end{array}$ & $\begin{array}{c}\text { Predicted Plant } \\
\text { Exergy Efficiency } \\
\text { Equation (26) (\%) }\end{array}$ \\
\hline $\mathrm{A}$ & 28.20 & 2.23 & 58.99 & $14,200.00$ & 35.40 & 37.08 \\
$\mathrm{~B}$ & 30.00 & 2.43 & 53.65 & $14,600.00$ & 34.90 & 42.74 \\
$\mathrm{C}$ & 33.00 & 2.49 & 57.68 & $13,500.00$ & 38.30 & 38.47 \\
\hline
\end{tabular}




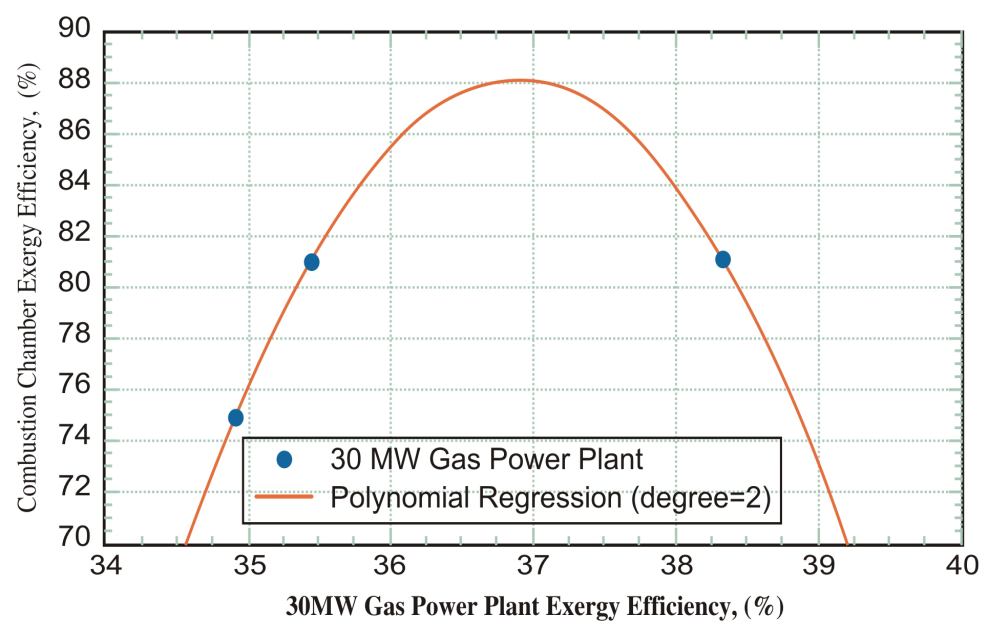

Figure 7. The combustion chamber exergy efficiency as a function of the rational exergy efficiency of a $30 \mathrm{MW}$ gas power plant.

\section{Conclusions}

On the basis of the analyses of the thermodynamic performance of the major components of three operational gas power plants in Lagos Nigeria, each with a rated capacity of $30 \mathrm{MW}$ but from different Original Equipment Manufacturers (A, B and C), the heat rate shows that plant $\mathrm{C}$ is the most fuel efficient of the three plants. The rational exergy efficiency is found to be a useful parameter in identifying and quantifying the possible areas of reduction in thermodynamic losses and improvement in efficiencies of major components in a gas power plant. The analysis has demonstrated that the rational exergy efficiency of a gas power plant $\left(\varepsilon_{p}\right)$ for a given power output $\left(P_{\text {out }}\right)$ is a function of the heat rate, $(H R)$, the mass flow rate of the fuel $\left(\dot{m}_{F}\right)$ and the thermal energy efficiency of the combustion chamber $\left(\eta_{c c}\right)$. A relationship between the rational exergy efficiency and the heat rate of the gas power plant in this study has been shown to be:

$$
\varepsilon_{p}=1-\left[1.08 *(H R) * P_{\text {out }} * \eta_{c c}\right] /\left[\dot{m}_{F} * 3600 *(L H V)\right]
$$

This relationship has been validated to explain the operational rational exergy efficiency of each of the three gas power plants (A, B and C) in the study.

The exergy efficiency of the combustion chamber which provides the maximum exergy destruction in gas power plants is shown to exhibit the following correlations with its thermal energy efficiency and the plant rational exergy for the $30 \mathrm{MW}$ capacity gas power plants.

$$
\varepsilon_{c c}=9.56+1.22 * \eta_{c c}
$$

with a correlation coefficient of 0.966 .

And

$$
\varepsilon_{c c}=-4523+250 * \varepsilon_{p}-3.4 * \varepsilon_{p}^{2}
$$

with a correlation coefficient of 1.0. 
The theoretical maximum mass flow rate of fuel in a $30 \mathrm{MW}$ gas power plant, $\left(\dot{\mathrm{m}}_{\mathrm{F}}\right)_{\max }=7.40 \mathrm{~kg} / \mathrm{s}$, has been shown to correspond to when the rational exergy efficiency approaches the Carnot efficiency of the plant. However, practical operational mass flow rate of the fuel has been shown to correspond to about one-third of the theoretical maximum mass flow rate of fuel.

The novelty in the study is the demonstration that the exergy efficiency of a 30 MW gas power plant can be estimated for a given heat rate provided the output power, mass flow rate of the fuel and the thermal efficiency of the combustion chamber are known.

The practical implication is that from an operational and component selection viewpoint in the specifications of a gas power plant, knowledge of the Heat Rate which is usually provided by the OEM is adequate to make a reasonable inference on the performance of some critical components of the plant.

\section{Acknowledgements}

The authors would like to acknowledge with thanks the support given by the management of AES Nigeria Barge Operations Ltd. to the authors in the provision of the operational data used in this study.

\section{Conflicts of Interest}

The authors declare no conflicts of interest regarding the publication of this paper.

\section{References}

[1] Kotas, T.J. (1995) The Exergy Method of Thermal Plant Analysis. 2nd Edition, Krieger Publishing Company, Malabar, Florida, USA.

[2] Dincer, I. and Rosen, M.A. (2013) Exergy, Energy, Environment and Sustainable Development. 2nd Edition, Exergy Handbook, Elsevier, Oxford, UK.

[3] Egware, H.O. and Obanor, A.I. (2013) Exergy Analysis of Omotosho Phase 1 Gas Thermal Power Plant. International Journal of Energy and Power Engineering, 2, 197-203. https://doi.org/10.11648/j.ijepe.20130205.13

[4] Cengel, Y.A. and Boles, M.A. (2006) Thermodynamics: An Engineering Approach. Fifth Edition, McGraw-Hill, New York.

[5] Ebadi, M.J. and Gorji-Bandpy, M. (2005) Exergetic Analysis of Gas Turbine Plants. International Journal of Exergy, 2, 31-39. https://doi.org/10.1504/IJEX.2005.006431

[6] Rosen, M.A. and Bulucea, C.A. (2009) Using Exergy to Understand and Improve the Efficiency of Electrical Power Technologies. Entropy, 11, 820-835. https://doi.org/10.3390/e11040820

[7] Mousafarash, A. and Ameri, M. (2013) Exergy and Exergo-Economic Based Analysis of a Gas Turbine Power Generation System. Journal of Power Technologies, 93, 44-51.

[8] Rogers, G.F.C. and Mayhew, Y.R. (1995) Thermodynamics and Transport Properties of Fluids. 5th Edition, Oxford Basic Blackwell Publishers, Britain.

[9] Querol, E., Gonzalez-Regueral, B., Jose, L. and Perez-Benedito (2012) Practical Ap- 
proach to Exergy and Thermo-Economic Analyses of Industrial Processes. Springer, Berlin.

[10] Pehelkin, Yu.M. (1967) Combustion Chambers of Gas Turbine Engines. Report \# FTD-MT-24-306-0 of the Foreign Technology Division Air Force Systems Command, U.S. Air Force. 


\section{Nomenclature}

Greek Alphabet

$\varepsilon$. Exergy efficiency

$\mathcal{E}_{D}$ : Exergy destruction efficiency

$\eta_{\mathrm{AC}}$ : Isentropic efficiency of air compressor

$\eta_{\text {Carnot: }}:$ Carnot Efficiency

$\eta_{\mathrm{CC}}$ : Combustion efficiency

$\eta_{\mathrm{GT}}$ : Isentropic efficiency of gas turbine

$\psi$. Exergy content

Lower case letters

$c_{P}$ : Specific heat capacity at constant pressure $(\mathrm{kJ} / \mathrm{kgK})$

gacc: Acceleration due to gravity $\left(\mathrm{m} \cdot \mathrm{s}^{-2}\right)$

$h$ : Specific enthalpy $(\mathrm{kJ} / \mathrm{kg})$

hcoeff: Convective heat transfer coefficient $\left(\mathrm{W} / \mathrm{m}^{2} \cdot \mathrm{K}\right)$

$\mathrm{k}$ : Ratio of specific heat capacities

$\dot{m}$ : Mass flow rate of working fluid [air/fuel] $(\mathrm{kg} / \mathrm{s})$

$\dot{m}_{a}$ : Mass flow rate of air $(\mathrm{kg} / \mathrm{s})$

$\dot{m}_{f}$ : Mass flow rate of fuel $(\mathrm{kg} / \mathrm{s})$

$\dot{m}_{e}$ : Mass flow rate of exhaust gas $(\mathrm{kg} / \mathrm{s})$

s. Specific entropy (J/kg K)

$u$ : Specific internal energy $(\mathrm{J} / \mathrm{kg})$

$v$. Velocity $\left(\mathrm{m} \cdot \mathrm{s}^{-1}\right)$

$z$. Height (m)

Upper case letters

$A$ : Area $\left(\mathrm{m}^{2}\right)$

CTD: Compressor discharge temperature $\left({ }^{\circ} \mathrm{K}\right)$

$C T I$ : Compressor inlet temperature $\left({ }^{\circ} \mathrm{K}\right)$

E: Exergy

$\dot{E}_{\text {destroyed }}:$ Exergy destruction rate

$E_{F}$ : Chemical exergy of fuel

$E_{M}$ : Mechanical exergy stream of component

$E_{T}$ : Thermal exergy stream of component

$H H V$ : Higher heating value $(\mathrm{kJ} / \mathrm{kg})$

$H R$ : Heat Rate $(\mathrm{MJ} / \mathrm{kWh})$

$L H V$ : Lower heating value $(\mathrm{kJ} / \mathrm{kg})$

$M C R$ : Maximum Continuous Rating

$P$ : Pressure (bar)

$P A$ : Ambient pressure (bar)

$P_{c}$ Pressure at location $\mathrm{c}$ (bar)

$P C D$ : Compressor discharge pressure (bar)

$P_{F}$ : Fuel pressure (bar)

$P_{1}$ : Pressure of air before compression (bar)

$P_{2}$ : Discharged pressure of air after compression (bar) 
$P_{3}$ : Pressure of gas at the inlet of turbine (bar)

$P_{4}$ : Pressure of gas after expansion (bar)

$Q$ : Heat transfer energy (J)

$Q_{C}$ : Heat transfer through the boundary at temperature Tc at location c (J)

$\dot{Q}_{C}$ : Heat transfer per unit mass through the boundary at temperature Tc at location c (W)

$\dot{Q}_{\text {Surr }}$ : Heat loss per unit mass to the surrounding (W)

$R$ : Specific gas constant $(\mathrm{kJ} / \mathrm{kg} \mathrm{K})$

$S_{\text {gen }}$ : Entropy generation $(\mathrm{kJ} / \mathrm{kg} \mathrm{K})$

SLT: Second Law of Thermodynamics

T: Temperature $\left({ }^{\circ} \mathrm{K}\right)$

$T_{\dot{C}}$ : Temperature at location $\mathrm{c}\left({ }^{\circ} \mathrm{K}\right)$

$T_{F}$ : Temperature of fuel $\left({ }^{\circ} \mathrm{K}\right)$

TIT: Turbine Inlet Temperature $\left({ }^{\circ} \mathrm{K}\right)$

$T P$ : Total Gas Power Plant

$T_{0}$ : Reference temperature $\left({ }^{\circ} \mathrm{K}\right)$

$T_{1}$ : Inlet temperature of air to the compressor $\left({ }^{\circ} \mathrm{K}\right)$

$T_{2}$ : Exit temperature of air after compression $\left({ }^{\circ} \mathrm{K}\right)$

$T_{2 \mathrm{~s}}$ : Isentropic temperature of air at compressor exit $\left({ }^{\circ} \mathrm{K}\right)$

$T_{3}$ : Inlet temperature to the turbine after combustion $\left({ }^{\circ} \mathrm{K}\right)$

$T_{4}$ : Exit temperature of gas after expansion $\left({ }^{\circ} \mathrm{K}\right)$

$T_{4 \mathrm{~s}}$ : Isentropic temperature of exhaust gas at turbine exit $\left({ }^{\circ} \mathrm{K}\right)$

$U$ : Internal energy $(\mathrm{J})$

$V$ : Volume $\left(\mathrm{m}^{3}\right)$

$W$ : Boundary work through the system (J)

$\dot{W}$ : Exergy flow rate or Useful work per unit time of the system (W)

$\dot{W}_{\text {net }}$ : Net Exergy flow rate of the unit or system (W)

$\dot{W}_{\text {rev }}$ : reversible work per unit time (W)

$\underline{\text { Subscripts }}$

A: Air

B: Boundary

AC: Air Compressor

c: Localized point

C: Compressor

CC: Combustion Chamber

coeff: Coefficient

Comb: Combustion

CV: Control volume

D: Destruction

exh: Exhaust

F: Fuel

g: Exhaust gas

gen: generation

GT: Gas turbine 
i: Initial state

j: Final state

M: Mechanical

o: Out

rev: Reversible

surr: Surrounding

T: Thermal

0 : Reference state or dead state

Superscripts

T: Thermal

M: Mechanical

1: Air compressor inlet state

2: Air compressor exit state

3: Combustion chamber exit state

4: Gas turbine exit state

F: Fuel 